\title{
THE RIGHT TO PRIVACY AND AMERICAN LAW
}

\author{
William M. BeANEY*
}

I

The Nature of a Right to Privacy

In his dissenting opinion in Griswold v. Connecticut ${ }^{1}$ Mr. Justice Black berated the majority for discovering and applying a constitutional "right to privacy." His reading of the Constitution failed to uncover any provision or provisions forbidding the passage of any law that might abridge the "privacy" of individuals. Therefore, he would have upheld a Connecticut act prohibiting the use of, or the giving advice concerning the use of, contraceptive devices. If Justice Black had examined state constitutions he would have found them similarly devoid of specific references to a "right to privacy:"

In private law, there are statutes and court decisions that protect various aspects of privacy and human dignity, frequently under property or contract concepts, but until very recent times these have not been viewed by the public or most legal commentators as spelling out a comprehensive "right to privacy." recognition of a "right to privacy" has been found in certain torts cases, dating from the first decade of this century and following the suggestion of the famous Warren and Brandeis article. ${ }^{3}$ The purpose of this paper is to describe some of the varied legal strands which, taken together, are beginning to form the structure of a modern right to privacy, the potential significance of which greatly exceeds the sum of meanings of the various separate legal rights and duties that are today catalogued under the rubric "right to privacy."

Since all of law and all "rights" in law represent authoritative efforts to define and influence the relationship of one or more persons or classes of persons to other individuals, groups, or classes, we must examine privacy as a series of legal claims

- A.B. 1940, Harvard University; LL.B. 1947, Ph.D. 1951, University of Michigan. Professor of Politics, Princeton University.. Author, ThE RJGHT to Counsel IN AMERICAN CourTs (1955); co-author [with Alpheus.T. Mason], The Suprexe Court in a Free Societr (1959).

${ }_{3} 8$ I U.S. 479,507 (1965).

${ }^{2}$ An obvious example is the protection of land ownership, or, more accurately, the possessory interest in land. Antitrespass statutes and common law rules protect the rightful possessor against those who might invade his privacy. Assault and battery doctrines have a similar protective effect.

${ }^{8}$ The Right to Privacy, 4 HaBv. L. Rev. 193 (1890):

- This paper is derived in large part from a longer working paper Privacy and the Law, prepared for the Special Committee on Science and Law of the Association of the Bar of the City of New. York, April 1964. Because this symposium presents detailed studies of many of the topics treated in my working paper, I have not dealt with these matters here. - For this reason, I may seem to ignore my own view that a "right to privacy" is meaningful only in so far as one can apply it to situations in the everydav world. 
with respect to desired or unwanted relationships with others, some of which have received protection in law while many others are pressing for but have not yet achieved legal recognition. ${ }^{5}$ One can readily discern at least three categories of claims that inhere in the legal concept of privacy at this time and must be given a place in any working definition of a right to privacy. Therefore a right to privacy as a legal concept can be defined as the legally recognized freedom or power of an individual (group, association, class) to determine the extent to which another individual (group, class, association, or government) may (a) obtain or make use of his ideas, writings, name, likeness, or other indicia of identity, or (b) obtain or reveal information about him or those for whom he is personally responsible, or (c) intrude physically or in more subtle ways into his life space and his chosen activities.

The rights and claims arising within these categories might well be characterized by a term other than "privacy." If the psychological concept of "personality" were less developed, one might propose "rights of personality" as a more positive shorthand way of expressing the congeries of claims now included in "privacy." "Human dignity" or "dignity of the individual" conveys a similar idea but with fewer negative associations than "right to privacy." "Privacy" has a largely negative meaning to many Americans, in the same sense that Warrens' and Brandeis's characterization of it as "the right to be let alone" may misleadingly suggest a sense of aloofness and withdrawal from everyday life. The concept "right to privacy" represents essentially an effort to define some reasonable rules for governing the behavior of active people whose work, play, and interactions are part of a highly complex interdependent society. The right is an affirmation of the importance of certain aspects of the individual person and his desired freedom from unreasonable intrusive conduct by others. The substance of the right as it has emerged over time is most clearly seen as the result of a series of favorable responses to claims arising out of conflictengendering situations in the real world.

\footnotetext{
"It should be noted that this statement concentrates on "rights" in law, that is, as defined or inferred from a constitutional system that operates within a context of law. It is not meant to imply that there are no criteria, moral or cthical, that may be applied to the law of the state. The typical mode of argument in favor of recognizing or increasing the protection of a claim has been to blend historical, philosophical, and sociological reasons in justification of a court decision or legislative enactment. We like to think that most law is "good" law and that the remainder is at least "neutral" in a moral sense. For a classic exposition, see Edward S. Coriwin, The "Higher Law" Background of Axierican CongtiTUTIONAL LAW (I955).

The difficulty is that each person has his own conception of the meaning of the word. The simplest notion is of being "let alone." But to many intelligent people the word has an cxcessively simple and negative quality.

"A "right of personality" is recognized in German law. For an informative discussion, sce Krause, The Right to Privacy in Germany-Pointers for American Legislation?, 1965 Duke L.J. 48x. It should be noted that the German courts constructed the right to privacy on the basis of two extremely general substantive articles in the 1949 West German Constitution: Article I( $x$ ), "The dignity of man shall be inviolable. To respect and protect it shall be the duty of all state authority"; and Article 2(I), "Everyone shall have the right to the free development of his personality, insofar as he does not infringe the rights of others or offend against the constitutional order or the moral code." Quoted in id. at 489 .
} 
Social Values and the Right to Privacy

To those who believe with Justice Black in a literal interpretation of the Constitution, and to all men who find repellent the notion that a right can emerge as part of the living law of society without a single formal act of creation, any discussion of a right to privacy will seem unreal and unsupportable. Those who prefer a system of law characterized by Austinian precision will inevitably be dismayed by an attempt to show that a common theme, and a central concept, may serve to unite disparate legal rules and principles into a meaningful new legal concept of significant social importance to a free society. ${ }^{\$}$ Yet, even the most strenuous advocate of a right to privacy must confess that there are serious problems of defining the essence and scope of this right. One danger is that of over-definition, by which "right to privacy" is used as a shorthand reference to an individual's freedom of thought and expression, freedom of religion, the guarantee of separation of church and state, and many other rights. ${ }^{9}$ At the other extreme is the deficiency of under-definition, which results from defining as a right to privacy only those claims which in the past have been clearly labeled "right to privacy" by a court or a legislature. ${ }^{10}$

If we are to think "things" and not words, as Holmes admonished, we must look at myriad human relationships, many of which are in the process of radical transformation as the result of new ways of carrying on governmental and private organizational activities. If the jurisprudence of the last century has taught us anything, it is the necessity of recognizing that law cannot be static, unless a society also is static. Although we have no certain touchstone for determining which of competing claims or interests deserve legal recognition at a given time, the one certainty is that a failure to examine the social situation in which claims are raised, or a mechanical reliance on existing law as reflecting a wise allocation of values that is still relevant, will heighten the gap betweer social ideals and legal realities. And although only a naive idealist would expect law to attempt to solve all questions and difficulties arising from social interactions and functions, we should recognize that a decision not to provide a legal solution means that we have accepted the existing private, nonlegal resolution of the issue and the triumph in fact of one set of claims over another. This, of course, does not necessarily mean that the real-life solution is viewed as satisfactory, but may reflect a conscious or intuitive judgment that the solution through law may have only

\footnotetext{
s The point is that the development of the right is not the result of a legal magician's trick but is a response to deeply felt social needs that emerge, at least originally, in the form of actual conflicts in the form of lawsuits.

${ }^{\circ}$ Justice William $O$. Douglas counts the right to travel, religious freedom, and, indeed, all rights of conscience among the various protected interests included in the right to privacy or the right to be let alone. Sec The Right of the People 87-165 (1958).

${ }^{10}$ Justice Black views the right to privacy solely as a ground for common law tort relief, or as a statutory right in those states where the legislatures have chosen to give protection. Griswold v. Connecticut, 381 U.S. 479, 5 I0 n.I (1965) (dissenting opinion).
} 
marginal value in the light of the problems raised and that this addition to the battery of interventions through law may, in itself, seem to have a doubtful or negative value from the wider perspective of life in a free society. To be specific, the claim of many Americans for a greater degree of freedom from unsolicited phone calls from pollsters and salesmen may generate substantial sympathy but fail to find support in law because of the difficulties of enforcement and the potential restriction of other, more praiseworthy, forms of uninvited communications, such as solicitations for charitable causes or by those engaged in scholarly research.

Most thoughtful people recoil from the principle that there should be a legal remedy for every social wrong, and are content with a selective process that elevates into a legal right only those claims that survive an assessment of the nature and extent of the probable moral and physical harm produced by an allegedly wrongful act. Admittedly, the way in which some claims succeed in gaining the protection of law while others arouse little response is almost never clearly evident. Many of our most fundamental rights appear as deceptively simple statements in the Constitution, where they have fulfilled at most an educative or admonitory function for long periods until suddenly they become the central focus of a sequence of claims that lead to interpretative judicial decisions. As the result we soon have an increasingly detailed, multi-faceted definition of rights and duties that constitutes the meaning of a guarantee of freedom of speech, for example, or equal protection of the laws.

'This is the process that is increasingly evident in the evolution of a right to privacy: While it is difficult to trace the antecedents of each facet of the right with any precision, one can identify at least the major sources of the right to privacy and, at the same time, can see more clearly the countervailing claims or interests that must be taken into account. For the basic process of balancing interest against interest that is at the heart of the definition of other rights will be found in the attempts through law to define a right of privacy. ${ }^{11}$ It is important to bring countervailing interests to the surface for discussion because the danger exists with respect to privacy claims, as with other rights, that its devotees may in zeal destroy other important values while pursuing their object with simple-minded devotion. While the chances of this occurring in the twentieth century United States may seem modest, the validity of privacy concepts can only receive strengthening from a process of testing claims

\footnotetext{
${ }^{11}$ The method of balancing interests, which has been the dominant approach used by Supreme Court Justices, has at times been tempered by the "preferred freedoms" doctrine, which had its origin in Chief Justice Stone's famous footnote in United States v. Carolene Prods. Co., 304 U.S. 144,152 n.4 (I938). Similarly, Justice Black has insisted on an absolutist interpretation of the Bill of Rights. Sce, e.g., Black, The Bill of Rights and the Federal Government, in The Great Rights 42 (Cahn cd. 1963). But the basic method of the common law judges and in constitutional jurisprudence has been to balance the freedom claim against the countervailing interest unless the claim was patently superior. In a real sense, that is a central element in any effort to justify a specific law, decision, or a system of authoritative rules: on reason and on balance of arguments, one resolution of issues seems more desirable, fairer than another, or more consistent with past decisions where similar conflicting interests were evaluated and the issue resolved by balancing.
} 
made in its name against others raised by reasonable men. In addition, we shall attempt in brief terms to examine the role of the various legal institutions in defining and applying this developing right.

\section{III}

\section{Sources of a Legal Right to Privacy}

The usual starting point in any discussion of the growth of the legal concept of privacy, though not necessarily the correct one, is the famous article; "The Right to Privacy," by Charles Warren and Louis D. Brandeis. ${ }^{12}$ Its publication date-I890represents to many modern minds the entrance upon a new, more sophisticated era in law, paralleling the attainment of industrial maturity and the onset of myriad social problems. But it is frequently reported without much comment that the article was occasioned by the prying, gossipy accounts of the social activities of members of Warren's family in a Boston newspaper that specialized in such revelations. It is difficult to conceive of a clash of interests from which it would be more difficult to extract a right to privacy. For although some of the most important court decisions reinforcing freedom of the press were yet to be handed down, the idea that a broadly defined freedom of the press was essential to the maintenance of a viable political system and an open society was widely held. And although we recognize that there are vast differences in the quality of newspapers and that "yellow journalism" is designed primarily to increase the sale of papers, we have been content to allow the least-principled publishers to enjoy the protection given their better-principled brethren, if for no other reason than the impossibility, illustrated by the I93I decision in Near v. Minnesota ex rel. Olson, ${ }^{13}$ of achieving agreement on what is reasonable and proper in the controversy-filled world of news reporting.

But if Warren and Brandeis were less than prescient in dealing with the countervailing power of the press, they were more convincing in their efforts to show that some existing English and American torts previously classified by the courts under property, contract, or implied trust rubrics were most meaningfully described as rights of privacy. What was truly creative was their insistence that privacy-the right to be let alone-was an interest that man should be able to assert directly and not derivatively from his efforts to protect other interests. To protect man's "inviolate personality" against the intrusive behavior so increasingly evident in their time, Warren and Brandeis thought that the law should provide both a criminal and a private law remedy. ${ }^{14}$

\footnotetext{
${ }^{12} 4$ Hanv. L. Rev. 193 (1890).

18283 U.S. 697 (193I).

14 Since newspapers will normally not regard an obscure person's activities as newsworthy unless he engages in a "newsworthy" act, the most frequent abuses of a right to privacy would arise from the publicizing of private acts of newsworthy people. But, leaving aside the problem of collecting substantial damages, how much will a suit for breach of one's privacy contribute to the privacy of the suitor? The dilemma is similar to that of the defamation victim except that the latter has to calculate
} 
It would be inaccurate to credit the tort concept of the Warren-Brandeis right to privacy with effecting any significant change in American life, but then, viewed in isolation, few legal concepts seem all-important. The approximately 350 decisions handed down between 1905 and 1965 , many of them under New York's statute prohibiting intrusive conduct "for the purposes of trade,"15 have had the effect of proscribing some of the more blatant, thoughtless, or intentional invasions of privacy, especially where a materialistic motive is evident, but we can only speculate as to a possible wider social effect of the right. ${ }^{16}$ And because of the unique totality of facts in many of the cases, it is difficult to state any general rules or principles; but this seems inherent in this area of law, since each case turns on the "reasonableness" of defendant's behavior under the circumstances. ${ }^{17}$ Whether newspapers and other media are influenced in some degree by the potentialities of lawsuits cannot be answered with assurance. The scandal-mongering type of publication, particularly those devoted to inside revelations about stars in the entertainment world, obviously base their operations on the "public-figure" status of their targets and the likelihood that few of their victims will choose to bring suit. A serious reporting medium will normally concentrate on newsworthy matters and have little reason to invade the humdrum world of ordinary people. There may appear to be a certain justice in thus protecting the privacy of the humble and obscure, but the privacy of the more prominent and active members of society may be in much greater danger. Yet, as noted above, the strong public interest in publicizing the activities of this latter group may outweigh their claims to privacy. ${ }^{18}$

It is, however, increasingly true that certain forms of visual and auditory surveillance, widely administered opinion surveys, intensively conducted behavioral research, and computerized data-gathering for various purposes may be rapidly destroying the privacy of the obscure "common man" as our society discovers new reasons for examining and taking account of the thoughts and behavior of masses of

whether the blow to his reputation resulting from a falsehood compels a suit. The harm from an invasion of privacy is clearly less tangible in its impact. For an extreme conclusion based on considerations of this variety, see Kalven, Privacy in Tort Law-Were Warren and Brandeis Wrong?, infra, pp. 326-4x.

${ }^{25}$ N.Y. Civ. Rughrs Law $\$ 5$ 50-5x.

${ }^{10}$ In defending the decision of the New York Court of Appeals in Roberson v. Rochester Folding Box Co., xyx N.Y. 538, 64 N.E. 442 (r902), denying the existence of a common law right to privacy, Judge O'Brien gave as one of the principal justifications the "commercial spirit of the age." "In his view" there was "little room left for those that would escape from the publicity that is born of its pushing and aggressive spirit." O'Brien, The Right of Privacy, 2 Colum. L. Rev. 437, 446 (Ig02).

${ }^{17}$ Dean Prosser, in a 1960 article, insists that there is not one but four distinct torts discoverable in the cases on privacy, each of which seeks to protect a distinctive individual interest. Privacy, $4^{8}$ Calip. L. REv. 383 ( 1960$)$. He has been persuasively answered by Edward J. Bloustein, who reaffirms the concept of a single tort, protective of a comprehensive right to individual human dignity against certain types of interference. Privacy as an Aspect of Human Dignity: An Answer to Dean Prosser, 39 N.Y.U.L. REv. 962 ( 1964$)$. See also Kalven, supra note $1_{4}$.

${ }^{18}$ Edward Shils has hypothesized that the hierarchical nature of British society has resulted in greater respect for privacy not only in governmental affairs but in socicty at large. The Torment of SEcrecy ch. 2 (1956). 
common people. ${ }^{19}$ For a variety of seemingly useful purposes, such as improved collection of taxes, more accurate determination of consumers' preferences, or the scientific study of how people think and act, the average man increasingly finds himself the object of official and unofficial scrutiny. Against most of these patterns of intrusive behavior, the tort remedy appears largely ineffective, either because the avowed justification of the intrusive action seems reasonable, especially when a zealous government cites increased efficiency or when the difficulty and expense of bringing suit seem excessive in the light of limited probable damages. ${ }^{20}$

Yet, it would be unwise to dismiss the importance of the tort remedy merely because it has not proved a panacea. It has the advantage of bringing to the surface examples of intrusive behavior that otherwise would go unnoticed. If exemplary damages were available against more serious invasionary acts, more suits would be initiated. ${ }^{21}$ In giving the individual at least a modest weapon with which to fight, the tort doctrine also serves an educative purpose, and its use may occasionally lead the way toward legislative and administrative action that on the whole may prove more decisive in combating standard types of intrusive behavior.

The more promising means of safeguarding a right to privacy, however, lie in several areas of public law, although the interrelationships between these areas are not yet widely recognized. It is proposed to discuss briefly here some of the potentialities of defining and protecting a right to privacy through constitutional interpretation, legislative enactments, and administrative rules and decisions. A final word is also added concerning the responsibilities of private groups in protecting individual privacy and inculcating a concern for its preservation.

\section{IV}

\section{The Constitutional Dimensions of Privacy}

\section{A. Derivation of the Constitutional Principle}

Whether one welcomes or despises the propensity of Americans to regard the Constitution as the embodiment of our most cherished values, it is a fact of our political life that a constitutional right is more dearly prized than one proclaimed

\footnotetext{
${ }^{19}$ See Santued Dash, Robert E. Knowlton \& Richard F. Schwartz, The Eavesdroppers (1959); Vance Packard, The Naked Society (I964); Mrron Brenton, The Privacy Invaders (I964); Ruebhausen \& Brim, Privacy and Behavioral Research, 65 Colvm. L. Rev. II84 (1965); Hearings on Invasion of Privacy by Government Agencies Before the Subcommittee on Administrative Practice and Procedare of the Senate Committee on the ludiciary, 89th Cong., Ist Sess. (1965); Hearings on Invasion of Privacy Before a Subcommittee of the House Government Operations Committee, 8gth Cong., Ist Sess. (1965); Hearings on Psychological Testing Procedures and the Rights of Federal Employees Before the Subcommittee on Constitutional Rights of the Senate Committee on the ludiciary, 8gth Cong., Ist Sess. (1965).

${ }^{20}$ The tort remedy against most governmental intrusions is weak or nonexistent.

${ }^{21}$ Especially if the trend toward making legal services available to those of modest or low incomes continues. But the unattractiveness of the contingent fee case will certainly restrict the bringing of suits until juries, or judges, take a more serious view of breaches of privacy.
} 
solely by legislative act, and, as we know, any novel or doubtful piece of legislation must inevitably run the gauntlet of judicial scrutiny of its constitutionality.

We may begin again with Mr. Justice Black, who asked in effect and answered negatively the question, "Does the Constitution guarantee a right to privacy?" Although not always fully consistent in his literal application of the Bill of Rights to the federal government and, through the fourteenth amendment, to state action, his fundamental belief that the justices exceed their authority when they depart from the specific text of the written document has respectable support in our constitutional tradition. ${ }^{22}$ But it is clearly not the only rational way of interpreting and applying an eighteenth century document to problems and situations that were unforeseeable in $1787 .^{23}$ Apart from the warning of Madison and others that the enumeration of certain rights would tend to disparage claims to others, an argument rejected by those supporting a "Bill of Rights," it is hard to see how several of the specific rights can be given meaningful scope without necessarily safeguarding a right to privacy. It would be indeed ironic if this were not so in a constitutional system designed to protect the integrity of the individual in an age that laid stress on the necessity of recognizing both the rational and irrational elements in man but which, above all, wanted to protect his dignity and status as an individual. Why should his freedom to express his thoughts receive protection if his thoughts could be extracted from him by the government? And why protect him in his home against arbitrary arrest and official searches if the government may use electronic or other scientific ways of observing and eavesdropping?

The great contribution of Brandeis in his famous Olmstead dissent ${ }^{24}$ was his drawing of the distinction between the interest to be protected and particular forms of invasion of that interest. In his view, the devising and ingenuity of man in substituting new scientific techniques for the older, heavy-handed secret observation of the thoughts, words, and acts of others should not be allowed to succeed in outflanking the law..$^{25}$

It follows from Brandeis's approach that if one is permitted counsel in his defense,

"Ane of the early statements is by Mr. Justice Iredell in Calder v. Bull, 3 U.S. (3 Dall.) 386,398 (1798) (concurring opinion). His target, which is also Justice Black's, was the use of "natural justice" arguments to invalidate legislation that was not prohibited by a specific constitutional provision.

1s When an extraordinary majority is required for formal amendment one usually has the choice either of "amending" (or adjusting) by interpretation or permitting the Constitution to become increasingly irrelevant to current needs. The effort to combine both the security of stated principles and the adaptability through changing interpretations, although dismaying to logicians and absolutists, has been the chief characteristic of our constitutional jurisprudence.

"Olmstead v. United States, 277 U.S. 438 , 47 I (1928).

25 The essence of Brandeis's position is that provisions protecting individual and group rights should be interpreted in the light of changing conditions just as provisions granting power are interpreted to reflect social and economic changes. Justice Black in Griswold asserts that government can do anything not prohibited by a specific provision. $38 \mathrm{r}$ U.S. at 5 ro. Brandeis would reject that position in favor of one that envisages both restrictions on, and powers of, government as subject to continued reinterpretation and changing application. 
the state should not diminish that right by overhearing a defendant's consultation with his attorney. ${ }^{26}$ If a right to teach a foreign language, ${ }^{27}$ of parents to have their children attend private schools, ${ }^{28}$ or of citizens to travel ${ }^{29}$ are implicit in the concept of freedom or inferable from specific provisions, it is a defensible mental step to conclude that the Constitution also protects freedom from unreasonable intrusions into an individual's or group's life-space and from assaults on their dignity and autonomy.

One of the most interesting of constitutional developments has been the search for a suitable rationale for protecting the privacy of groups against state efforts to identify members and through various other stratagems to make hazardous the enjoyment of a right to association. ${ }^{30}$ Clearly, there cannot be an unlimited right to the privacy of associations that seek undesirable social objectives or whose methods of operation run afoul of reasonably applied conspiracy doctrines. In undertaking this very ticklish process of separating permissible from prohibitable associational activity the Supreme Court has taken a long step toward bringing constitutional guarantees into closer alignment with social realities. For better and for worse, individuals today frequently find meaningful avenues for asserting personal and social claims only through associational activity. But some forms of associational activity may threaten the freedom, including the right to privacy, of other individuals and groups. A weighing of ends and means is clearly required, and, as in so many other situations where we seek to use law to shape conduct, resolution of issues in individual cases is difficult and any rule of law other than a rule of reason is virtually unthinkable. Whether or not one agrees with the Court's performance in balancing interests to protect the NAACP while allowing harassment of the $\mathrm{Ku} \mathrm{Klux} \mathrm{Klan}$ and the Communist Party, U.S.A., ${ }^{31}$ there are sufficient differences between both means and ends to make plausible a different treatment in law of these associations.

Finally, one can view the heightened concern of the Supreme Court for extending the equal protection of the laws in various ways to disadvantaged individuals and

\footnotetext{
se There is little doubt that the Supreme Court would so hold, if a case were presented. A wiretap would be barred by 47 U.S.C. $\$ 605$ ( 1964 ) (unauthorized publication or use of wire or radio communications), but my reference here is to other forms of electronic eavesdropping. The Supreme Court has recently agreed to consider several cases involving eavesdropping of a non-wiretapping nature. See United States v. Osborn, 350 F.2d 497 (6th Cir. 1965), cert. granted, 382 U.S. ro23 (1966) (clandestine tape recording of defendant's incriminating revelations to undercover agent); United States v. Black, 216 F. Supp. 645 (W.D. Mo. 1963), aff'd, 353 F.2d 885 (D.C. Cir. 1965), cert. denied, 384 U.S. 927 (I966), memo requested on motion for rehearing, 384 U.S. 983 (I966) (secret microphone apparently used to monitor defendant's conversations). In the Black case, the federal government revealed in its memorandum to the Supreme Court that defendant's premises had been "bugged" but that information gathered was not used against defendant in a tax evasion trial. See N.Y. Times, July 14, 1966, p. I, col. 8.

${ }^{27}$ Meyer v. Nebraska, 262 U.S. 390 (1923).

${ }^{28}$ Pierce v. Society of Sisters, 268 U.S. 510 (1925).

${ }^{20}$ Kent v. Dulles, 357 U.S. II6 (1958).

${ }^{30}$ Bates v. City of Little Rock, 36I U.S. 516 (1960); NAACP v. Alabama ex rel. Patterson, 357 U.S. 449 (1958). Compare these cases with the earlier decision in New York ex rel. Bryant v. Zimmerman, 278 U.S. 63 (I928), where a New York law requiring membership lists was upheld in its application to the Klan.

${ }^{32}$ See Dennis v. United States, 34 I U.S. 494 (I95I).
} 
minorities as an important step toward protecting the privacy of ever-larger numbers of people. In one sense, this is merely the obvious point that equality in fact tends to mean that rights formerly enjoyed by some will now be the possession of many. But with respect to privacy values, which have often been viewed as a primary concern only of higher status individuals, the effort through law to enhance the privacy and dignity of disadvantaged individuals and groups, whether criminal suspects, religious or racial minorities, or welfare clients, tends to strengthen the claims to privacy and dignity of all citizens.

\section{B. The Weighing of Privacy and Conflicting Claims}

When the Supreme Court decides a case involving a privacy claim, what claims and counterclaims does it seek to balance and with what consistency does it justify its determination for or against the assertion of a right to privacy? Perhaps by examining several examples of clashing interests we can at least suggest the range of considerations open to the Court, permitting the opinions to stand as justification for what the Court did, in fact, decide.

(I) Public Utilities Commission v. Pollak ${ }^{32}$ involved a Washington, D.C., bus rider's resistance to an imposed diet of radio music, news, and advertising on privately owned but publicly regulated buses. The Public Utilities Commission upheld this additional service to the commuter as "not inconsistent with public convenience, comfort, and safety." The court of appeals reversed on the ground that a constitutional right to privacy had been violated. On review the Supreme Court held that the Public Utilities Commission had acted within its statutory powers and had not violated any constitutional right of riders under the first or fifth amendments. In rejecting the privacy claim, the Court, speaking through Mr. Justice Burton, argued that when a traveler left his home and rode on public transportation, he had to accept reasonable regulations in the interests of the general convenience of paśsengers. The Court seemed impressed by the results of a public opinion survey showing that 93.4 per cent of riders were not opposed to transit radio and only three per cent were firmly opposed. 'In short, whether a conventional balance-of-interests test or a test of reasonableness was applied, the claim to privacy of a very small minority had to yield. ${ }^{33}$ Only Mr. Justice Douglas saw a violation of a broad right to privacy, protected by the first, fourth, and fifth amendments, in subjecting a captive audience to radio programs. He spurned the Court's apparent willingness to let the preferences of a dominant majority determine the limits of an individual's claim to privacy.

Whether or not one likes the outcome in Pollak, it raises in an unusually focused

\footnotetext{
${ }^{82} 343$ U.S. 451 (I952).

s8 Perhaps the emphasis should not be placed on the small number of claimants of the right in this case but rather on the insubstantiality of the interest. We have become so conditioned to auditory assaults in stores, restaurants, and other public and semi-public places, that canned music secms as natural as the air we breathe (to the pollution of which buses have also contributed).
} 
way the problem confronting courts when the freedom claim has relatively few proponents, when the possible injury to these claimants seems relatively slight, and when the constitutional basis is somewhat novel. In a concurring opinion in Pollak, Mr. Justice Black noted that had bus riders been subjected to public news or propaganda, their first amendment rights would have been violated, but, unlike Justice Douglas, he found no violation of the due process clause of the fifth amendment.

(2) Griswold v. Connecticut ${ }^{34}$ found the Court receptive to a claim that Connecticut law prohibiting the use, or advice concerning the use, of contraceptives violated the right to privacy of married persons and was therefore unconstitutional. The disagreement of members of the majority as to the constitutional underpinning of the claim is less important than the fact that they agreed that a right to privacy had a constitutional basis and that the justification for the Connecticut act was inadequate. In this case we have no detailed statistics showing how people in Connecticut or elsewhere viewed the activities that the state sought to prevent, nor had the state shown any intention of enforcing the act by invading the privacy of the home. But, on its face, the state law ran counter to an ever-widening acceptance in American society of the principle of birth control and, if taken seriously, would threaten the intimacies of family life. And, as Justice White demonstrated in his concurring opinion, the state interest in preventing illicit sexual relations could have been served with equal effectiveness by more narrowly focused statutory provisions. ${ }^{35}$

(3) Acceptance of the use by law enforcement officials of electronic devices to obtain evidence where no trespass has been committed points up the reluctance of the Court to extend the concept of a right to privacy. In Silverman v. United States, ${ }^{36}$ the Court agreed that the use of a spike microphone constituted a trespass and that the resulting eavesdropping was in violation of the fourth amendment. The earlier cases had relied on the much criticized Olmstead ${ }^{37}$ rationale, that in the absence of a trespass there is no illegal search when electronic eavesdropping takes place. ${ }^{\mathbf{3 8}}$. In spite of the decision in Lopez $v$. United States, ${ }^{39}$ upholding the use of a recording

\footnotetext{
${ }^{84}{ }_{381}$ U.S. 479 (1965). My preference is for the formulation of Mr. Justice White, concurring, to the effect that the Connecticut law deprived married couples of part of their "liberty" guaranteed by the fourteenth amendment. In effect, liberty, with its manifold meanings, can serve quite as effectively as "penumbras" as a bar to unreasonably intrusive legislation. Here, at least, the results are the same.

${ }^{35}$ This is a principle that has been used erratically by the Court and can be attacked on the ground that a statute either is, or is not, unconstitutional regardless of alternative measures that might have slighter effects upon freedom. But if one is to balance interests, it seems reasonable to take into account discernible alternatives. To permit a legislative body or administrator to select the more oppressive means of achieving socially desirable goals is to condemn freedom values to a subordinate position in most conflicts.

${ }_{36} 65$ U.S. 505 (I96r).

37 Olmstead v. United States, 277 U.S. 438 (1928).

${ }^{88}$ See On Lee v. United States, 343 U.S. 747 (I952); Goldman v. United States, 3 I6 U.S. I29 (1942).

${ }^{30} 373$ U.S. 427 ( 1963 ). It is interesting to note that United States v. Osborn, 350 F.2d 497 (6th Cir. 1965), cert. granted, 382 U.S. 1023 (1966), is now pending in the Supreme Court and involves an issue strikingly similar to that in Lopez.
} 
device by an Internal Revenue agent to obtain proof that he had been offered a bribe by a delinquent taxpayer, it is unlikely that the trespass factor will continue to distinguish a permissible auditory invasion from a prohibited one. Certainly the "invasion" in Lopez was of the least reprehensible kind-that of an honest official seeking to protect his own reputation as well as enforcing the law against bribery. But with the growing public concern over police and private use of electronic devices, the public interest in security of homes and offices will tend to outweigh the official need to use these devices for law enforcement and security purposes, when the courts are confronted with ordinary cases. The spirit that infused the Court's decision in Boyd v. United States ${ }^{40}$ and Brandeis's dissent in Olmstead ${ }^{41}$ is likely to pervade applications of the fourth amendment in the future, with the stress on protection of the interest in privacy, rather than on the specific manner in which that interest is adversely affected.

What we see emerging is a substantial acceptance by the Court of the importance of individual privacy-dignity and the need to protect that set of interests against unreasonable government action. The replacement of the human eye, ear, and nose by more sophisticated technical devices is increasingly seen not merely as a refinement in the older techniques of surveillance but as a revolutionary step in stripping individuals of their privacy. ${ }^{42}$ And since the Court has shown little dismay because of the charge that their decisions invalidating convictions frequently permit guilty men to go free, it will hardly think that some decline of law enforcement effectiveness is too great a price to pay for enhancing the right to privacy. A sharp increase in the incidence of certain crimes might, however, induce the Court to weigh the interests with a different result in the future. Nor is it impossible to conceive of judicially controlled official eavesdropping that might survive attack on fourth amendment grounds. ${ }^{43}$

(4) The Supreme Court has upheld administrative searches by health officials acting under laws that authorized searches of homes and other premises without warrant. In the first case, Frank v. Maryland, ${ }_{4}^{44}$ there was substantial evidence outside the suspected home of possible rat infestation. In Ohio ex rel. Eaton $v$. Price,

${ }^{10}$ II6 U.S. 616 (I886).

41277 U.S. at 471 (1928).

42 This is obviously not accepted by those who argue that new techniques represent mere refinements of established ways of observing others and that if a policeman may legally report what he sees or hears, the fruits of the new devices should be admissible. But it is because we have rcasonably effective means of protecting ourselves from the unwanted snooping of policemen and others that the new devices are sought in order to break through the individual's available defenses.

${ }^{48}$ Schwartz, On Current Proposals to Legalize Wiretapping, 103 U. PA. L. REv. 157 (1954), concludes that wiretapping, because of its illimitable "search" of conversations, could not meet constitutional warrant requirements. Kamisar, The Wiretapping-Eavesdropping Problem: A Professor's View, 44 MinN. L. REv. 89I ( 1960 ), disagrees. His argument is that if wiretapping is not a conventional means of searching, its limitations should be tested by other than the conventional requirement of a description of the "things to be seized."

" 359 U.S. 360 (1959).

${ }^{45}{ }_{3} 6$ U.S. 263 ( 1960$)$. 
the request to inspect a private house was part of a random process. Here the clash of interests is more complex than might first appear. It is not simply a question of public health versus privacy but whether the decision to inspect, at a time of an inspector's own choosing, is reasonable in the light of a resident's desire to be free from such inspection or, alternatively, his insistence that a warrant is necessary. Arguably, a warrant requirement would severely handicap an inspection system, but, on the other hand, few householders would insist that one be obtained. ${ }^{46}$ One would assume that routine inspections might be preceded by at least a general notice of intention to inspect in certain areas, but in the Ohio case no notice was given. If a similar case were to arise today, the Court might well invalidate an inspection system that lacked both warrant and notice provisions, at least when there was a lack of evidence tending to show a need for inspection without delay. Public opinion may serve as a significant limiting factor, but the most likely targets of overzealous inspectors will be the homes and establishments of those of lower socioeconomic status and not those of the opinion-leaders of the community.

In the foregoing cases and others the Supreme Court has toiled valiantly, though with difficulty, to fashion a legal concept protective of privacy from constitutional provisions and principles. There is every reason to believe that a right to privacy with constitutional underpinnings will find increasing recognition and application in the future. ${ }^{47}$ As an essential facet of human freedom and dignity, a right to privacy has found a stout champion in a Court devoted to the protection of the freedom and equality of individuals and groups at a time when they are increasingly threatened by public and private action. To say that the Court has not yet succeeded in discovering a formula that can be applied readily to any situation that may arise is only to recognize a condition of constitutional jurisprudence that is characteristic whenever important claims or interests clash. What the Court has been doing in a somewhat tentative way is to insist that privacy-dignity claims deserve to be examined with care and to be denied only when an important countervailing interest is shown to be superior.

\section{V}

\section{Nonjudicrax Protection of the Right to Privacy}

In the preceding sections we have examined the common law and constitutional foundations of the concept of a right to privacy. But the courts, as we fully recognize,

\footnotetext{
"Again, it may be doubted whether the conventional warrant requirement is meaningful in this context. Unless there is external evidence of a health hazard, what can a warrant "describe" when the inspection is intended to determine whether reasonable health standards are being observed by the householder? See Beaney, The Constitutional Right to Privacy in the Supreme Court, I962 Sur. Cr. Rev. 212, 244-46; Comment, State Heatlh Inspections and "Unreasonable Search": The Frank Exclusion of Civil Searches, 44 MinN. L. REv. 5 I3 (I960).

${ }^{47}$ The quantum of freedom is not a fixed sum, but seems to be capable of expansion to meet the changing demands and higher standards of society. While the retrogressive possibilities should not be ignored, the trend in the United States since I920, though with many halts and some setbacks, has been toward greater recognition, and protection of the libertarian claims of individuals and groups.
} 
are limited in their power to shape conduct and to affect the progress of events. Cases based on the common law or the Constitution arise only when an individual feels sufficiently aggrieved to become a plaintiff, and large areas of human interaction thus remain largely free from judicial scrutiny. For the most part, courts can only pronounce judgment that this or that action is wrong; their prescriptive powers are slight. This suggests that if there are patterns of official and private behavior that raise privacy issues, reliance solely on the courts is insufficient and that wherever possible we should look to legislation, administrative action, or private value choices for protection of the right to privacy and dignity. ${ }^{48}$

\section{A. The Legislative Role}

While one would be extremely naive to assume that Congress and the state legislatures or local law-making bodies will embark on a sustained campaign to protect the privacy of Americans from every form of invasion, the legislatures have been aroused by documented revelations of intrusive activities in both private and governmental life. ${ }^{49}$ Of course, a show of concern and the massing of evidence through staff studies and public hearings may not necessarily result in legislation, but at the very least a useful educational function is served. And in many cases, the administrative agencies whose activities come under scrutiny will make efforts to reform, if only to escape the possibility of unwanted controls or other punitive impositions. ${ }^{.0}$ Without attempting a complete listing of the areas where legislative concern has been demonstrated or of those deserving investigation, some of the possible targets should be noted.

There should be an obvious concern for invasions of privacy arising out of the potential, or actual, employment relationship. Especially in large-scale enterprises, management has sought to learn certain vital facts about a prospective employee-Has he been convicted of crime? Is he honest? Is he a sexual deviate? Does he lead a "normal" life?-by the use of lie detectors, probing personality tests, and other intrusive means. ${ }^{\mathbf{1}}$ Once hired, similar techniques may be used to determine an employee's general conduct and fitness for promotion or to test his asserted innocence

\footnotetext{
${ }^{18}$ The effect on privacy values of the scope of federal governmental operations has been the subject of recent congressional hearings. See, e.g., Hearings on Invasion of Privacy by Government Agencies Before the Subcommittee on Administrative Practice and Procedure of the Senate Committee on the ludiciary, 8gth Cong., xst Sess. (1965); Hearings on Invasion of Privacy Before a Subcommittce of the House Government Operations Committee, 8gth Cong., Ist Sess. (1965); Hearings on Psychological Testing Procedures and the Rights of Federal Employees Before the Subcommittee on Constitutional Rights of the Senate Committee on the Judiciary, 89th Cong., Ist Sess. (1965).

${ }^{40}$ In many instances, legislatures and administrative agencies will receive their cues from court decisions, and the most desirable situation would find each legal instrumentality doing its share of the work, with a division of labor shaped by the capabilities of each.

${ }^{0}$ The activities of the congressional committees cited in note 48 supra and the fear of stringent legislation have reputedly helped to induce sudden concern for the dignity and well-being of human subjects in behavioral research sponsored by the National Institutes of Health and other federal agencies. See generally Ruebhausen \& Brim, supra note 19.

${ }^{01}$ See Brenton, op. cit. supra note 19, at 6r-116; PACkard, op. cit. supra note 19, at 47-72.
} 
of theft or embezzlement. ${ }^{52}$ Because of widespread use of one or more of these intrusive techniques, it is useless to suggest that an affected individual need not accept a position or continue in employment with a firm that uses undesirable practices. While some labor unions have shown concern, the traditional reluctance of legislatures to control internal relationshps within the world of industry has, thus far, led to little legislation.

The reluctance of legislatures to intervene where management practices threaten privacy-dignity extends to other private spheres, and we should recognize that some very basic beliefs about the proper role of government and law in a free society lie behind the refusal of legislatures to act. Nevertheless, if corporate managers, labor union leaders, university administrators, and other key figures in control of private organizations adopt practices that threaten important privacy values, legislatures will eventually feel compelled to act, particularly if one or more interest groups raise the issue and elicit public support-which is more easily obtained as the public becomes more fully informed of the frequency and scope of invasionary practices.

It is, of course, possible that many of the laws enacted to combat intrusive behavior in the private sectors of society will amount to little in practice. One can point to state laws prohibiting wiretapping that are rarely, if ever, enforced. ${ }^{63}$ Ignoring the obvious difficulties in enforcing wiretapping laws, it can be argued that the mere existence of such laws is to some extent a deterrent to private wiretapping, either because of fear of detection and punishment or because of moral inhibitions against violating a law. But statutes prohibiting or regulating private use of lie detectors, or narcoanalysis or the more intrusive kinds of personality tests, or restrictions on misleading or intrusive tactics of pollsters and market researchers, would seemingly be more readily enforced than the laws aimed at wiretapping. And the existence on the books of laws protecting privacy, coupled with the readiness of legislatures to enact additional legislation should the need arise, will undoubtedly have a salutary effect on those in private life who determine the extent to which the lives of others will be subject to intense scrutiny and other invasionary practices. ${ }^{54}$

The increasing attention given by legislatures to the activities of private investigators and lie detector technicians suggests one fruitful line of attack. The imposition of higher licensing standards and the requirement of fuller disclosure of their methods of operation, together with more effective policing of the less scrupulous, would greatly improve the ethical standards of these groups. It may be that the development through legislation of licensing and other requirements for the various classes of operatives whose skills and activities pose threats to privacy is the most promising technique for achieving reasonable control over their activities.

\footnotetext{
"arenton, op. cit. supra note I9, at II7-37; PACKARD, op. cit. supra note I9, at 73-102.

${ }^{83}$ See Dash, KNowlton \& Schwartz, op. cit. supra note I9, at 161-230.

5t This "educative" and admonitory function of law is frequently underrated. Because the enactment of a law is not followed by a substantial number of prosecutions, the legislative contribution is not, therefore, meaningless.
} 
Whatever the difficulties in trying to eliminate or moderate intrusive behavior in the private sector, there are fewer reasons for legislative inaction with respect to the conduct of government officials. In spite of past descriptions of the world of the government administrator as that of a "headless fourth branch" and criticisms of the extensive discretionary powers given to certain administrative agencies and officials, a more realistic appraisal is that administrators are not only extremely conscious of law and rules but operate in an atmosphere of fear lest they incur the disfavor of the relevant committee of the legislature. ${ }^{55}$ Thus, legislative bodies are strategically placed for insisting that their progeny-the administrative agenciesobserve reasonable standards of behavior.

If the local law-making and appropriating bodies were to interest themselves in the day-to-day performance of law enforcement agencies that adversely affect privacy, it is unlikely that illegal or undesirable activities would continue. ${ }^{56}$ Similarly, the ways in which health and fire inspectors, welfare investigators, and other officials affect the privacy of the objects of their attention can be subjected to legislative scrutiny. ${ }^{57}$ Even if no legislation results, the legislative investigation, a device which has itself been used on occasion for unreasonably intrusive forays but is more consistently employed in the exercise of legislative oversight, can have an important impact on the way in which administrators deal with the public.

Whether legislatures can be induced to maintain a systematic review of administrative behavior affecting privacy is doubtful. It would be helpful, for example, if one or more subcommittees maintained a constant surveillance of the information gathering activities of government. There may be plausible reasons for accumulating more and more information about each citizen, in order to improve efficiency of tax collection or to permit planners and administrators in other agencies to carry out their functions more efficiently, since any government agency operates more rationally when provided with adequate information. But clearly there are data that lie outside the pale of government concern and other matters that must be treated as confidential and with stringent safeguards of confidentiality. ${ }^{58}$ For the most part, the

\footnotetext{
${ }^{55}$ See generally Josepfi P. Harris, Congressional Controc of Administration (1964).

${ }^{\dot{B}} \mathrm{~F}$ For the most part, the quality of police and their observance of decent standards of behavior is directly related to the over-all efficiency of local governing bodies, which generally in the United States has been low.

${ }^{6}$ The new emphasis on equality in fact as well as in law for formerly disadvantaged and mute groups will surely carry over to this area.

${ }^{58}$ Statutes at all levels of government provide for confidentiality of various classes of data, reflecting the past concern of lawmakers for certain privacy values. See generally Karst, "The Files": Legal Controls Over the Accuracy and Accessibility of Stored Personal Data, infra, pp. 342-76, especially pp. $347-50,369-7 x$. It should be noted how carefully the Bureau of the Census guards the confidentiality of the business and other data under its control. When the Supreme Court held that file copies of reports furnished by businesses to the Bureau were subject to subpoena by the Federal Trade Commission, St. Regis Paper Co. v. United States, 368 U.S. 208 (196r), Congress quickly closed this gap in the protection of confidentiality. 76 Stat. 922 (I962), I3 U.S.C. $\$ 9$ (a) (I964). See Hearings on Confidentiality of Census Reports Before the House Committee on Post Office and Civil Service, 87th Cong., $2 d$ Sess. $(1962)$.
} 
information needed for efficient government operation concerns the needs, wishes, or behavior of human aggregates rather than of specific individuals. Much of the information could be gathered through contracts with private research organizations pursuant to which the identity of individuals would be concealed.

In conclusion, it can be argued that legislative bodies, because of their representative role and their crucial position as intermediaries between the working arms of government and the people for whose benefit government exists, have a largely unused capacity for drawing meaningful boundaries between permissible and undesirable forms of governmental action, in the light of their effect on privacy and dignity. They are unhampered by the limitations of case litigation and possess vastly greater resources than the courts for identifying and weighing the interests that oppose and those that support privacy claims. ${ }^{59}$

\section{B. Administrative Choices}

It would be grossly unfair to those entrusted with important administrative powers to assume that they are lacking in concern for privacy-dignity values. The vast majority of administrators are very sensitive to adverse reactions of their constituencies and the public in general and to any signs of displeasure from the legislature. But administrators are committed to the achievement of policy goals, and they are keenly aware of both internal and external pressures to perform their jobs efficiently. They are confronted by taxpayers seeking economical administration, special constituents demanding services, adversely affected parties who seek to divert their attention, and superiors wanting the credit for successful administration at the least cost in money and political enemies.

Either because of legal requirements or by choice, many government agencies are avid collectors of data relevant to their assigned functions. The Internal Revenue Service wants accurate data on financial transactions that affect tax liability. The Federal Trade Commission and the Antitrust Division of the Department of Justice seek data on business practices that may offend some provision of the antitrust laws. Local welfare agencies wish to avoid improper payments and cause unannounced nighttime visits to be made to the homes of recipients to determine if an allegedly deserting male has, in fact, returned. Law enforcement officials are under constant pressure to solve crimes, particularly those that are notorious, where there may be little evidence available through normal forms of surveillance. Any agency faced with a problem of employee turnover, or plagued by internal thefts, or whose work may be endangered by emotionally disturbed or morally deficient employees, will seek to avoid appointment of misfits or will seek to weed out those with dangerous habits or mental or moral deficiencies. Particularly where national security interests

\footnotetext{
${ }^{60}$ The chief disadvantage is the difficulty of evolving legislative standards that can be fitted to conduct that takes diverse and changing forms. And one danger that must be faced is that the enactment of legislation (or refusal to do so) may be interpreted by the courts as a restriction on judge-made law. See Yoeckel v. Samonig, 272 Wis. 430, 75 N.W.2d 925 (1956).
} 
are immediately involved, it is hardly to be expected that the dignity of the employee will loom large when the interests are balanced.

It would be fruitless and irrational to insist that privacy values should consistently receive preference over governmental action that threatens those values. If government, and only government, can perform many essential social functions, it is inevitable that individual citizens must yield to some extent their claim "to be let alone." What can be asked of the administrator, however, is his observance of certain safeguards: namely, that he examine the objectives to be obtained by the intrusive action, determine that these are indeed important, and assure himself $(a)$ that the means selected are necessary and appropriate; $(b)$ that there is no equally suitable means of attaining the objective that avoids an adverse effect on privacy values; $(c)$ that where the confidentiality of data is required by law, adequate safeguards will be observed to maintain confidentiality in fact; and $(d)$ that the agency provides some form of internal review of decisions that involve privacy issues.

Neither these nor any other set of prescribed procedures or considerations will eliminate or solve all the questions that may arise. But these or similar standards for administrative behavior can reduce needless invasions of privacy by sensitizing officials to some of the undesirable potentialities of their acts and by establishing institutional responsibility for the behavior of individual representatives. A special agency committee might be given special responsibility to review all proposed programs or specific actions that raise serious privacy-dignity issues. What must be recognized is the inevitability of differing views as to the correct balancing of issues, so that reasonable men may reach opposite conclusions as to whether an allegedly invasionary act is "reasonable." Application of a standard of "reasonableness" requires a calculation in which each element in the formula must be weighted according to the value system of the assayer. But this is hardly a novelty in the law, and what must be stressed is the extent to which shared values are so largely evident in most situations requiring judgment. Nor is it likely that the administration of important public programs will suffer because of a new concern for privacy-dignity values. It is hardly clear that use of a prying personality test is essential to good personnel policies, or that government cannot maintain its secrets without the use of lie detector tests on employees, or that a welfare program will be seriously harmed if investigators forgo midnight visitations. ${ }^{80}$

One positive result of administrative initiative in avoiding unreasonable intrusive practices is that the need for, and likelihood of, legislative intervention are diminished. And in spite of what has been stated above concerning the possible role of the legislature, it must be recognized that statutory treatment may be an extremely rough and insensitive way of dealing with the subtle conflicts of interests in this area. In attempt-

\footnotetext{
${ }^{10}$ Obviously, if the decisions to use intrusive methods are not subject to effective review by the agency, we can expect zealous officials to choose in favor of achieving policy goals. The common criticism of officials at all levels is that they lack a consuming interest to achicve policy goals.
} 
ing to deal with a flagrant and unique misuse of governmental power, the balance may be shifted too drastically in favor of privacy-dignity. For example, banning of all personality tests might cut off a potentially valuable tool in selecting employees for certain positions. Welfare investigators may, at times, be justified in making home visits at an unusual hour. A security investigation of those in sensitive positions seems patently reasonable. The administrator, then, is the most strategically placed official in the political system for determining how government can accomplish its goals without unreasonable threats to the privacy and freedom of the public.

\section{The Private Sector}

What has been said of the role of the government administrator applies, with modifications, to those who hold executive and administrative positions in the various organizations and associations that affect our daily lives more immediately and in many cases more substantially than do governmental agencies. In the myriad decisions, procedures, relationships, and activities that make up the world of business, labor organizations, universities, and other private entities, the living law of society is constantly being applied, refined, reshaped to meet the felt needs of the society, To the extent that those possessing the power of decision in these private worlds choose to incorporate a concern for privacy-dignity values in the "due process" rules and standards that they announce and enforce, the demand and need for the formal legal system to respond will be minimized. For, at heart, the values that find expression in legal decisions, statutes, or administrative rules and orders must reflect the consensus of the leaders of opinion and action in the wider society. While judges, lawmakers, and administrators have a capacity for helping to teach us to select the more desirable of competing values, they in turn are instructed and informed by the acts and beliefs of those who shape the society of which they are a part. The protection of privacy-dignity values, then, is not solely a task for the law but part of a never-ending quest to increase the respect of all men for the essential values of human life. 